\title{
A systematic review on the genetic analysis of paragangliomas: primarily focused on head and neck paragangliomas
}

\author{
Minireview
}

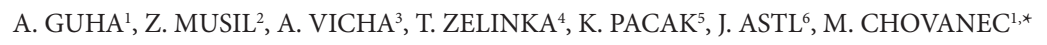

${ }^{1}$ Department of Otorhinolaryngology, $3^{\text {rd }}$ Faculty of Medicine and Kralovske Vinohrady University Hospital, Charles University in Prague, Czech Republic; ${ }^{2}$ Department of Biology and Medical Genetics, $1^{\text {st }}$ Faculty of Medicine and General University Hospital, Charles University in Prague, Czech Republic; ${ }^{3}$ Department of Pediatric Hematology and Oncology, $2^{\text {nd }}$ Faculty of Medicine and University Hospital Motol, Charles University in Prague, Czech Republic; ${ }^{4}$ Department of Endocrinology and Metabolism, $1{ }^{\text {st }}$ Faculty of Medicine and General University Hospital, Charles University in Prague, Czech Republic; ${ }^{5}$ Section on Medical Neuroendocrinology, Eunice Kennedy Shriver National Institute of Child Health and Human Development, National Institutes of Health, Bethesda, MD, USA; ${ }^{\circ}$ Department of Otorhinolaryngology and Maxillofacial Surgery, $3^{\text {rd }}$ Faculty of Medicine and Military University Hospital, Charles University in Prague, Czech Republic

${ }^{*}$ Correspondence: martin.chovanec@fnkv.cz

Received December 8, 2018 / Accepted May 6, 2019

\begin{abstract}
Paragangliomas and pheochromocytomas are rare, mostly benign neuroendocrine tumors, which are embryologically derived from neural crest cells of the autonomic nervous system. Paragangliomas are essentially the extra-adrenal counterparts of pheochromocytomas. As such, this family of tumors can be subdivided into head and neck paragangliomas, pheochromocytomas, and thoracic and abdominal extra-adrenal paragangliomas. Ten out of fifteen genes that contribute to the development of paragangliomas are more susceptible to the development of head and neck paragangliomas when mutated. Gene expression profiling revealed that pheochromocytomas and paragangliomas could be classified into two main clusters ( $\mathrm{C} 1$ and $\mathrm{C} 2$ ) based on transcriptomes. These groups were defined according to their mutational status and as such strongly associated with specific tumorigenic pathways. The influence of the main genetic drivers on the somatic molecular phenotype was shown by DNA methylation and miRNA profiling. Certain subunits of succinate dehydrogenase (SDHx), von Hippel-Lindau (VHL) and transmembrane protein 127 (TMEM127) still have the highest impact on development of head and neck paragangliomas. The link between RAS proteins and the formation of pheochromocytomas and paragangliomas is clear due to the effect of receptor tyrosine-protein kinase (RET) and neurofibromatosis type 1 (NF1) in RAS signaling and recent discovery of the role of HRAS. The functions of MYC-associated factor X (MAX) and prolyl hydroxylase 2 (PHD2) mutations in the contribution to the pathogenesis of paragangliomas still remain unclear. Ongoing studies give us an insight into the incidence of germline and somatic mutations, thus offering guidelines for early detection. Furthermore, these also show the risk of mistakenly assuming sporadic cases in the absence of definitive family history in head and neck paragangliomas.
\end{abstract}

Key words: head and neck paraganglioma, somatic mutation, germline mutation, SDH, VHL, TMEM127

Paragangliomas and pheochromocytomas (PPCs) are rare, mostly benign vascular neuroendocrine tumors of paraganglial cell clusters, which are embryologically derived from neural crest cells that have comigrated with autonomic nervous system. These tumors can be associated with either the sympathetic tissue in adrenals as pheochromocytomas (PHEOs) and extra-adrenal locations as sympathetic paragangliomas (sPGLs) or the parasympathetic tissue of the head and neck as head and neck paragangliomas (HNPGLs) [1]. PHEOs have the highest relative incidence. Second most common are HNPGLs, which are the subject of this review. HNPGLs with estimated incidence of 1-30/100000 per year represent about 3\% of all head and neck tumors [2]. These tumors may occur at any age, although vast majority of patients become symptomatic between fourth and seventh decade of life. There is a 3-4:1 female predominance [3].

Nomenclature of HNPGLs is based on the site of origin. Carotid paragangliomas (also known as carotid body tumors) represent the most common type [4-6]. Other frequently detected HNPGLs are tympanic, jugular and vagal paragan- 
gliomas [7-9]. Facial nerve, orbital, sinonasal, parotid gland, cervical sympathetic chain, laryngeal, esophageal, thyroid and parathyroid paragangliomas are extremely rare [3, 10-13].

Symptoms of HNPGLs depend on the site and extent of the tumor. According to the site of origin, patients can present with a range of symptoms from painless, slowly enlarging neck mass to lower cranial nerves and sympathetic trunk deficits. HNPGLs are usually slow growing tumors that are benign in the majority of cases although malignancy rates up to $10 \%$ have been reported. However, there are no accepted histopathological or immunohistochemical criteria for the diagnosis of malignant paragangliomas. The only evidence of a malignancy is the presence of local or distant metastases (that is, presence of paraganglial cells in non-neuroendocrine tissue). Rinaldo et al. reviewed the literature and reported the highest malignancy rate for sinonasal paragangliomas (24\%), followed by vagal tumors (10\%), jugulotympanic paragangliomas $(5.1 \%)$, carotid paragangliomas (1.41\%) and laryngeal paragangliomas (1.36\%) [14].

\section{Hereditary PPCs}

PPCs can occur sporadically or as a part of hereditary syndromes $[7,15-17]$. Hereditary tumors can be suspected in case of familial antecedents of the disease, multiple tumors and early onset of the disease. Sporadic tumors are usually diagnosed in patients older than $40-50$ years [18]. Until recently, only $10 \%$ of PPCs were associated with hereditary syndromes namely von Hippel-Lindau disease, multiple endocrine neoplasia type 2, and neurofibromatosis type 1 , resulting from a germline mutation in the tumor suppressor gene von Hippel-Lindau (VHL) [19], proto-oncogene RET [20] and tumor suppressor gene neurofibromatosis 1 (NF1) [21] respectively. Tumors associated with these syndromes are predominantly pheochromocytomas. Since the beginning of the 21st century, it has become apparent that about $35 \%$ of sporadic PPCs are due to a germline mutation in one of susceptible genes $[7,22]$. These are as follows the four subunits of the succinate dehydrogenase (SDHx) complex (e.g. SDHA, SDHB, SDHC, SDHD) [23-26], succinate dehydrogenase complex assembly factor 2 (SDHAF2), VHL [19], protooncogene RET [20], NF1 [21], transmembrane protein 127 (TMEM127) [27], MYC-associated factor X (MAX) [28] and the recently discovered fumarate hydratase $(\mathrm{FH})$ and malate dehydrogenase 2 (MDH2) [29]. In addition, germline and also somatic mutations of other genes were reported [30], namely kinesin family member 1B (KIF1b) [32], EGLN1/ prolyl hydroxylase 2 (PHD2) [32], isocitrate dehydrogenase 1 (IDH1) [33], hypoxia-induced factor 2 alpha (HIF-2a) [34] and Harvey Retrovirus-associated DNA sequences (HRAS) [35].

\section{Hereditary factors and tumorigenesis}

It should be noted that over the last few years, several large-scale genomic analyses have been conducted world- wide on independent series. These include comparative genomic hybridization and single nucleotide polymorphism (SNP) array, mRNA and microRNA expression studies [36] as well as methylation profiling $[37,38]$. These approaches have led to the description of well-defined tumor subtypes and their corresponding tumorigenic pathways [39]. Gene expression profiling revealed that PPCs could be separated by unsupervised analysis into two main clusters: cluster 1 (C1) and cluster 2 (C2) based on transcriptomes [1, 40-43]. DNA methylation and miRNA profiling showed a major influence of the main genetic drivers on the somatic molecular phenotype [29, 36-38]. Cluster 1 can be further subdivided into C1A and C1B. In C1A, DNA and histone hypermethylation is observed in SDHx, fumarate hydratase $(\mathrm{FH})$ and malate dehydrogenase 2 (MDH2) gene linked tumors [44, 45]. Whilst in C1B, glycolysis is activated in VHL related tumors, HIF-2 $\alpha$ and PHD2 [34, 39, 43, 44]. Germline or somatic mutations in this cluster were characterized by transcription signatures indicating reduced oxidoreductase activity, and thus increased angiogenesis and hypoxia [44, 46]. According to the Knudson's two-hit theory, heterozygous germline mutations in SDHx tumor suppressor genes are usually associated with somatic loss of the non-mutant allele in the tumor (i.e. loss of heterozygosity). This results in inactivation of SDH enzymatic activity and thereby accumulation of succinate, which acts as an inhibitor of prolyl hydroxylase (PHD) enzymatic activity. PHDs represent enzymes crucial for the degradation of HIF. As a consequence, even in the presence of oxygen, HIF cannot be degraded via proteasomemediated degradation driven by VHL protein. It is stabilized to induce angiogenesis and tumorigenesis $[30,46]$. The latter also happens in VHL mutations. Interestingly, Letouze et al. have recently described a hypermethylator phenotype in SDH-related paragangliomas. These tumors accumulate succinate, which inhibits 2-oxoglutarate-dependent histone and DNA demethylase enzymes, resulting in epigenetic silencing, thereby affecting neuroendocrine differentiation $[1,37]$. The gene expression signatures of Cluster 2-related tumors include genes that mediate translation initiation, protein synthesis, adrenergic metabolism, neural/neuroendocrine differentiation and abnormal activation of kinase signaling pathways, such as RAS/RAF/MAPK and PI3K/ $\mathrm{AKT} / \mathrm{mTOR}$. The genes in $\mathrm{C} 2$ are namely RET protooncogene, NF1, TMEM127 [27], MAX and HRAS [44].

\section{Cluster 1 \\ Succinate dehydrogenase (SDH) mutations - according to chronological order. \\ SDHD - paraganglioma syndrome type 1}

The discovery of SDHD mutations in families with paraganglioma syndrome type 1 (PGL1) was in 2000. This led to understanding of the molecular mechanism of paragangliomas inheritance [23]. Baysal et al. also revealed, in their study, that germline mutations in the SDHD gene are 
located at 11q23.18 [23]. Later in 2009, Pasini and Stratakis extensively reviewed 95 international manuscripts on SDHx mutations comprising a total of 395 SDHD mutation carriers [47]. Since then, several other large patient case series have also been reported, describing the genotype-phenotype correlation of SDHD mutations [18, 48, 49]. Multiple tumors are a key feature of this syndrome and can be seen in $60 \%$ to $79 \%$ of affected patients. They can be either synchronous or metachronous. HNPGLs affect about $91-98 \%$ of patients with PGL1 $[7,18,30,47,48,50]$. The risk of developing sympathetic paragangliomas is $16 \%$ to $60 \%[7,18$, 48]. SDHD mutations are common in HNPGLs, which are vastly biochemically silent [51], that is, with the exception of $20 \%$ that secrete dopamine and/or its metabolite methoxytyramine. This can be useful for monitoring these patients [51].

The inheritance pattern in this syndrome is also of significant interest. It was observed that PGL1 families exhibit a peculiar inheritance pattern with a distinct "parent-of-origin dependent effect" [52]. Although SDHD mutations can be inherited both via the maternal and paternal lines, paragangliomas almost never develop after maternal transmission of the mutation [7, 30, 53-55]. As maternally derived SDHD mutation carriers will still pass the mutation to their offspring in $50 \%$ of cases, PGL1 can skip generations. This may in part explain the occurrence of SDHD germline mutations in apparent nonfamilial cases. Furthermore, an individual who inherits a SDHD pathogenic variant from his/her father is at high risk of manifesting paragangliomas and, to a lesser extent, pheochromocytomas [16]. Imprinting of SDHD has never been established, and the fact that this inheritance pattern is also found in PGL2 families (linked to the SDHAF2 gene, located on 11q13), but not in PGL3 or PGL4 families, suggests that other factors related to chromosome 11 lead to this phenomenon [7]. Neumann et al. first published data on age-related penetrance in SDHD mutation carriers in 2004 [56]. SDHD mutations showed $50 \%$ penetrance by age 31 rising to $86 \%$ by the age of 50 . In a study by Hensen et al. done in 2009, age-related penetrance in patients with SDHD was $54 \%$ by age 40 and $87 \%$ by age 70 . The average range of age at diagnosis of SDHD-linked tumors was 25 to 38 years [57]. HNPGLs affect about $40 \%$ of patients with PGL1 with median age at the time of diagnosis being 40 years $[7,37$, 51]. Pheochromocytomas that affect about half of the PGL1 patients present at earlier age than HNPGLs [7]. van Hulsteijn et al. presented a systematic literature review and metaanalysis in 2012 on the risk of malignant paragangliomas in SDHD mutation carriers. Their findings showed that the prevalence of malignant tumors varied widely, ranging from $0 \%$ to $23 \%$. The pooled incidence for malignant paragangliomas was $8 \%$ in SDHD mutation carriers [58].

\section{SDHC - paraganglioma syndrome type 3}

Paraganglioma syndrome type 3 (PGL3) is associated with mutations of SDHC, located on chromosome 1q21 [25,
59]. In contrast to patients with PGL1 and PGL4, SDHC mutation carriers mostly present with single HNPGLs. Multiple HNPGLs are found only in about $19 \%$ to $31 \%$ of patients. Pheochromocytomas, extra-adrenal paragangliomas including malignant tumors are rarely reported $[18,48$, 60-62]. In comparison to PGL1 and PGL4, PGL3 is a rare disease $[18,48,63]$. Two large series of patients consisting of 598 and 445 patients with HNPGLs presented by Neumann et al. and Burnichon et al. have shown similar prevalence of $3.6 \%$ and $4.3 \%$ for SDHC mutations, respectively $[18,48]$. However, risk of developing HNPGLs with PGL3 is almost $100 \%[7,62,63]$. Family history is positive in the minority of patients with SDHC mutations (12\% to $25 \%$ ), suggesting a low tumor penetrance [48]. The average age at diagnosis is higher than for the other syndromes (ranging from 38 to 46 years) [62].

\section{SDHB - paraganglioma syndrome type 4}

Syndrome associated with mutations of SDHB gene, located on chromosome 1p36.13, was designated as paraganglioma syndrome type 4 (PGL4) $[24,59]$. Patients with SDHB mutations frequently develop sPGLs (52\% to $84 \%$ ) and PHEOs (18\% to $28 \%$ ). Extra-adrenal sympathetic paragangliomas have long been known to have a greater predisposition to malignancy than PHEOs and HNPGLs [64]. It is not clear whether this effect is the result of location, variant status, or both [65]. The risk of developing HNPGLs in PGL4 is $27 \%$ to $31 \%$ [18]. Multifocal HNPGLs are significantly less frequent (in 8\%) $[7,18,47,66]$. The estimated age-related tumor penetrance in SDHB mutation carriers is $29 \%$ at age 30 rising to $45 \%$ at age 40 [50]. HNPGLs usually present later compared to PHEOs and sPGLs during the course of this syndrome.

Mutations of SDHB were associated with malignant PHEOs and HNPGLs in $20.6-41 \%$ cases [7, 18, 47, 66]. It has also been shown that patients with a germline SDHB pathogenic variant can develop malignant PPCs at any site $[43,50,56,67,68]$. The systematic literature review and meta-analysis done by van Hulsteijn et al. on the risk of malignant tumors in SDHB and SDHD mutation carriers, revealed a pooled incidence of $17 \%$ in the SDHB group. The pooled risk in prevalence studies, ranged from $13 \%$ to $23 \%$ in the SDHB group [58]. Furthermore, multivariate analysis of a series of 54 patients done in France for malignant PPCs demonstrated that identification of SDHB mutation was the only risk factor for mortality. The 5-year survival probability was $36 \%$ for patients with SDHB mutation versus $67 \%$ for patients without SDHB mutation [67].

\section{SDHAF2 - paraganglioma syndrome type 2}

The susceptibility gene for paraganglioma syndrome type 2 (PGL2) was identified in 2009 [69] and located on chromosome 11q13.1 [7]. SDHAF2 affects flavination of SDHA. A 
follow-up multicenter study was undertaken in Spain and the Netherlands with the joint aims of identifying new mutation carriers and assessing the frequency of SDHAF2 mutations amongst 443 sporadic PPCs. It became clear that mutations in this gene make a very modest contribution to the overall genetic burden in these syndromes. All currently affected mutation carriers were identified to be affected exclusively with HNPGLs [45]. Only one additional SDHAF2-related family was identified in Spanish patients, which interestingly carried the exact mutation, p.Gly78Arg, previously discovered in the Netherlands. A familial relationship to the Dutch kindred was excluded $[45,55,70]$. The same study also concluded SDHAF2 mutation analysis is justified in very young patients with isolated HNPGL without mutations in SDHD, SDHC, or SDHB, and in individuals with familial antecedents who are negative for mutations in all other risk genes. Interestingly, the Dutch kindred with PGL2 showing frequent occurrence of HNPGL, was collected in Netherlands over a 30-year period [71]. This family was originally described in 1981 [70]. Over 30 years, in 3 generations, 72 living family members were traced and linkage analysis was carried out in 57 members. The findings associated with the same mutation were age at diagnosis below 40 years, $100 \%$ affected at age $50,100 \%$ with HNPGLs and $91 \%$ with multifocal tumors [71]. So, the risk of developing HNPGLs with PGL2 is close to $100 \%[14,18,30,33,45,70,71]$.

\section{SDHA - paraganglioma syndrome type 5}

In 2010, the mutation in the gene of the final subunit in the mitochondrial complex, SDHA, located on chromosome 5 p15 was linked to PPCs [26]. Although HNPGLs have been detected with mutations in SDHA, the risk of developing such tumors remains unknown [59].

\section{Fumarate hydratase (FH) and malate dehydrogenase 2 (MDH2)}

$\mathrm{FH}$ and $\mathrm{MDH} 2$ are two enzymes belonging to the tricarboxylic acid cycle [39]. The incidence of FH mutation in PPCs is estimated at about 1\%. Mutations in FH predispose to hereditary leiomyomatosis and renal cell carcinomas. Interestingly, about $40 \%$ of cases carrying germline $\mathrm{FH}$ mutation presented a metastatic paragangliomas [29, 39]. Only one germline $\mathrm{MDH} 2$ mutation has been identified in a patient with multiple malignant PPCs [39]. However, cases of HNPGLs were not detected.

\section{von Hippel-Lindau (VHL)}

von Hippel-Lindau syndrome is caused by inactivation of the tumor suppressor gene VHL located on chromosome 3 p25-p26 [19, 59, 72]. The VHL protein regulates the activity of hypoxia-inducible factor-alpha (HIF- $\alpha$ ) and cellular processes, including angiogenesis. VHL syndrome is charac- terized by a predisposition to multiple tumor types. It can be classified according to the risk of developing PPCs. VHL type 1 patients are predisposed to retinal angiomas, central nervous system hemangioblastomas and renal carcinomas. VHL type 2, specifically subtype $2 \mathrm{C}$, predisposes patients to PPCs without any type 1 tumors. The age of onset of PPCs in patients affected by von Hippel-Lindau syndrome is approximately 30 years $[30,73]$. The rate of de novo mutations is approximately $20 \%$ [15]. One study detected somatic mutations of the VHL gene in about $14 \%$ of sporadic PPCs [44]. The prevalence of hereditary HNPGLs in patients with VHL mutation is reported to be $0.5 \%[72,74]$.

\section{Hypoxia-inducible factor 2-alpha (HIF-2a)}

In 2012, novel somatic mutations in the gene encoding HIF- $2 \alpha$ in 2 patients were identified in Bethesda. One presented with paraganglioma and the other with paraganglioma and somatostatinoma, both of whom had polycythemia [34]. The existence of a new syndrome (potentially to be named Pacak-Zhuang syndrome) was confirmed in 4 female patients of different ethnicities [75, 76]. Locus of this gene is 2p21-p16 [59]. These patients were found to have polycythemia either at birth or in childhood together with multiple paragangliomas and somatostatinomas. Hypoxiainducible factors are transcription factors controlling energy, iron metabolism, erythropoiesis, development, glycolysis and other cell functions. HIF- $2 \alpha$ mutations were found to disrupt prolyl hydroxylation. This results in a failure of HIF- $2 a$ ubiquitylation and it's degradation. Thus, the longer half-life of the mutant protein results in the upregulation of downstream targets (endothelin-1, erythropoietin, glucose transporter 1 or vascular endothelial growth factor). This is currently believed to be the pathogenic mechanism that leads to tumor development [34]. Interestingly only one patient on a follow up ${ }^{18} \mathrm{~F}-\mathrm{DOPA}$ PET/CT presented with jugular paraganglioma [75], otherwise no other HNPGLs have been reported.

\section{Prolyl hydroxylase domain-containing protein 2 (PHD2)}

The product of the PHD2 gene is a prolyl hydroxylase that is known to function in hydroxylation of hypoxia-inducible factor alpha and thus function in the cells response to hypoxia [83]. So far only one study described a patient with erythrocytosis and abdominal paragangliomas who was found to harbor a mutation in the PHD2 gene [32].

\section{Cluster 2 \\ Receptor tyrosine-protein kinase (RET) proto-oncogene}

The RET protein is a receptor tyrosine kinase that regulates cellular proliferation and apoptosis. It is located on chromosome 10q11.2 [7]. RET mutations have been associated with increased activation of PI3K/v-Akt signals and RAS/RAF/ 
MAPK signaling pathways [59]. This leads to the development of multiple endocrine neoplasia type 2 (MEN2). Patients with MEN2 are usually first diagnosed with medullary thyroid cancer (MTC), which is the most common condition in these patients. MEN2 is further subdivided into three categories: MEN2A, MEN2B and familial MTC (FMTC). MEN2A accounts for approximately $90 \%$ of cases. Patients with MEN2A and MEN2B have 100\% chance of developing MTC. MEN2 patients have also a $30-50 \%$ chance of developing pheochromocytoma. Patients with FMTC do not have a risk of developing PHEOs [6]. Both somatic and germline mutations of RET have been reported [15]. Due to the strong family history, carriers can be detected at an early age. Only one study detected somatic mutations of the RET gene in about $14 \%$ of sporadic PPCs [44]. Interestingly HNPGLs have only been described in 3 patients with MEN2. It should be noted that HNPGLs do not develop without other MEN2-associated manifestations [74].

\section{Neurofibromatosis type 1 (NF 1)}

NF1 gene encodes a GTPase activating protein, involved in multiple signaling cascades important to cellular growth and differentiation. It is located on chromosome 17q11.2 [59, 78]. Mutations of the gene lead to the neurofibromatosis type 1 syndrome (NF1) [77-79]. Hallmark of NF1 are multiple skin neurofibromas, cafe-au-lait spots, axillary freckling and Lisch nodules of the iris [7]. In addition, other tumors such as MTCs and carcinoids can also be seen [15]. However, the rate of PHEO/PGL development in NF1 is significantly lower than in VHL or MEN2 syndromes. Recently, somatic NF1 mutations have been linked to the pathogenesis of apparently sporadic PPCs [78]. Initially in 1987, 1 patient with NF1 syndrome was reported to have HNPGL [80]. But in recent times, large international analyses have not revealed any association with HNPGLs $[18,80]$.

\section{Transmembrane protein 127 (TMEM127)}

TMEM127 is a tumor suppressor gene located on chromosome 2q11.2 [59]. Mutations of TMEM127 have been related to PHEOs. These show transcriptional profile similar to NF1 and RET related tumors. However, neither RAS activation nor AKT phosphorylation were observed. It has been shown that the mammalian target of rapamycin complex 1 (mTORC1) is specifically affected by TMEM127 knockdown, leading to increased phosphorylation of targets of mTORC1 $[27,59]$. Genetic studies of PPC patients indicate a low prevalence of TMEM127 mutations (approximately 2\%) [27, 82]. A unique finding in these patients is the older average age ( 42 years) at presentation, which is similar to sporadic cases. In most cases, mutation carriers suffered from PHEOs only (unilateral as well as bilateral tumors) and secreted a high level of metanephrines. Only one patient with bilateral carotid paragangliomas was reported $[27,72,81]$.

\section{MYC-associated factor X (MAX)}

In 2011, MAX was identified as a new pheochromocytoma tumor suppressor gene in three independent patients with familial antecedents of the disease [28]. The protein encoded by the MAX gene is a member of the basic helix-loop-helix leucine zipper (bHLHZ) family of transcription factors. It is located on chromosome 14q23.3. MAX mutations are associated with bilateral PHEOs and show apparent paternal transmission of the disease [28]. In a large international study, it was confirmed that MAX germline mutations are responsible for PPCs in $1.12 \%$ of cases. Somatic mutations in MAX were found in $1.65 \%$ of cases [82]. No HNPGLs were reported till now.

\section{Harvey Retrovirus-associated DNA sequences (H-RAS)}

Constitutive RAS signaling is known to increase cell proliferation and induce tumor formation in several cancers [84]. This is located on chromosome 11p15.5 [85]. Genetic mutations of NF1 and RET are known to affect RAS signaling and are associated with the formation of PPCs. However, association of RAS mutation itself with PPCs was reported in a series of 4 male patients ( 3 presenting with PHEOs and 1 with sPGL) in 2013 [40, 85].

Considerable progress has been made in the genetics of paragangliomas over the last few years. Before 2000 , only one genetically determined form of the disease was thought to exist, but it has now been shown that about $30 \%$ of paragangliomas are genetically determined due to the presence of mutation in one of the 15 susceptibility genes identified to date. Only 10 of these genes have been related to HNPGLs (Table 1).

Growing understanding has led to changes in the management of our patients. It is now well established that all patients with a hereditary form of paragangliomas require genetic counseling and management by a specialized multidisciplinary team comprising surgeons, radiologists, nuclear medicine physicians, endocrinologists and geneticists. Multiple tumors, positive family history, age at diagnosis less than 40 years, presence of carotid body tumor as well as bilateral presentation should be considered hallmarks of germline mutations in HNPGLs [17, 18, 48, 85, 86, 87]. The clinical presentation including location of all type of tumors, multifocality as well as malignancy varies vastly with the gene mutated. Germline mutations in SDHA and SDHC are associated with HNPGLs and sympathetic paragangliomas. SDHAF2 mutations are associated with HNPGLs. SDHD and SDHB mutations are associated with HNPGLs, sPGLs and PHEOs, whilst TMEM127 and MAX with PHEOs [30]. SDHB mutations are generally associated with a higher incidence of malignant tumors compared to mutations in other SDHx genes [1]. Furthermore, germline mutations in SDHx also occur in around 30\% of HNPGLs that are regarded sporadic due to the absence of a family history [88], suggesting that these HNPGLs may be "occult familial" cases 


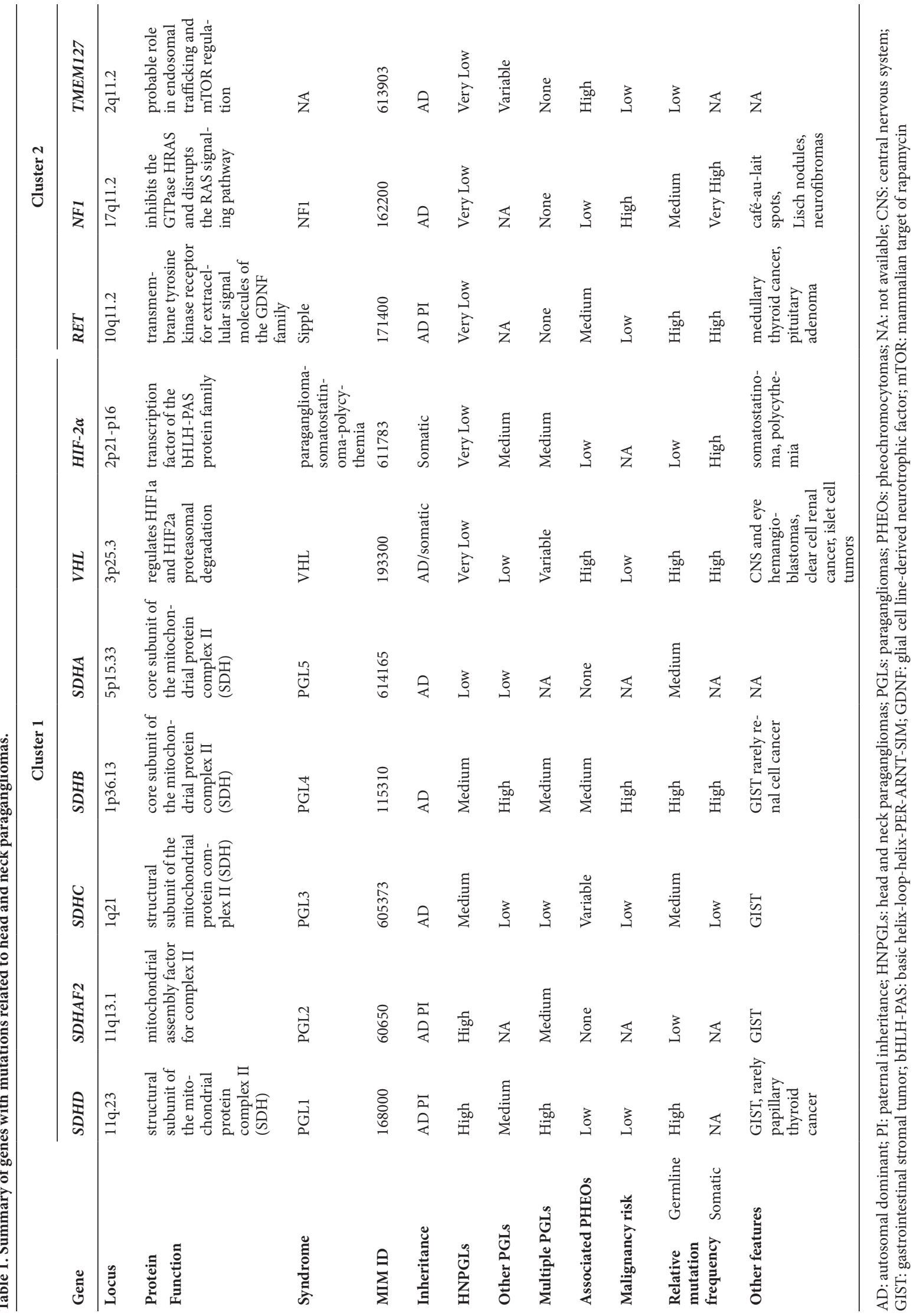


[89]. It should be mentioned that somatic mutations in other genes could be detected in another $30 \%$ of sporadic HNPGLs, mainly involving RET, VHL, NF1, HRAS and HIF2 $\alpha$ [34, 40, 90-92].

If PPCs are found without any syndromic or familial presentation, metastatic tumors should be tested for SDHB mutations. Multiple abdominal paragangliomas should be first tested for the presence of SDHB mutations and female patients with multiple paragangliomas associated with somatostatinomas, should be first tested for HIF $2 a$ mutations [85]. Furthermore, results support the fact that if patients are suspected of hereditary HNPGLs, they should undergo genetic testing first at the SDHD and SDHB loci, unlike familial paragangliomas at other sites, which are also associated with VHL and RET mutations [86]. Various recommendations have been suggested regarding early detection of mutations depending on family history, tumor site, character and location, multiplicity and presence of metastasis. However, the rarity of HNPGLs makes diagnosis and treatment a challenge.

Acknowledgements: PROGRES Q28 - Onkologický program II/ 3.LF, PROGRES Q28 - Onkologický program II/ 1.LF

\section{References}

[1] CORSSMIT EP, ROMIJN JA. Clinical management of paragangliomas. Eur J Endocrinol 2014; 171: R231-R243. https:// doi.org/10.1530/EJE-14-0396

[2] WASSERMAN PG, SAVARGAONKAR P. Paragangliomas: classification, pathology, and differential diagnosis. Otolaryngol Clin North Am 2001; 34: 845-862. https://doi. org/10.1016/S0030-6665(05)70351-0

[3] BOEDEKER CC. [Paragangliomas and paraganglioma syndromes]. Laryngorhinootologie 2011; 90 suppl 1: S56-82. https://doi.org/10.1055/s-0030-1270447

[4] SOBOL SM, DAILEY JC. Familial multiple cervical paragangliomas: report of a kindred and review of the literature. Otolaryngol Head Neck Surg 1990; 102: 382-390. https://doi. org/10.1177/019459989010200413

[5] SAJID MS, HAMILTON G, BAKER DM, JOINT VASCULAR RESEARCH GROUP. A multicenter review of carotid body tumour management. Eur J Vasc Endovasc Surg 2007; 34: 127-130. https://doi.org/10.1016/j.ejvs.2007.01.015

[6] NAIK SM, SHENOY AM, NANJUNDAPPA, HALKUD R, CHAVAN P et al. Paragangliomas of the Carotid Body: Current Management Protocols and Review of Literature. Indian J Surg Oncol 2013; 4: 305-312. https://doi.org/10.1007/ s13193-013-0249-4

[7] BOEDEKER C, HENSEN E, NEUMANN H, MALE W, VAN NEDERVEEN FH et al. Genetics of hereditary head and neck paragangliomas. Head Neck 2014; 36: 907-916. https:// doi.org/10.1002/hed.23436

[8] JACKSON CG, GLASSCOCK ME, HARRIS PF. Glomus tumours: Diagnosis, classification and management of large lesions. Arch Otolaryngol 1982; 108: 401-410.
[9] BILLER HF, LAWSON W, SOM P, ROSENFELD R. Glomus vagale tumors. Ann Otol Rhinol Laryngol 1989; 98: 21-26. https://doi.org/10.1177/000348948909800105

[10] WATSON DJ. Nasal paraganglioma. J Laryngol Otol 1988; 102: 526-529.

[11] LANGERMAN A, ATHAVALE SM, RANGARAJAN SV, SINARD RJ, NETTERVILLE JM. Natural History of Cervical Paragangliomas: outcomes of Observation of $43 \mathrm{~Pa}$ tients1993-2010. Arch Otolaryngol Head Neck Surg 2012; 138: 341-345. https://doi.org/10.1001/archoto.2012.37

[12] BARNES L. Paraganglioma of the larynx. A critical review of the literature. ORL J Otorhinolaryngol Relat Spec 1991; 53: 220-234. https://doi.org/10.1159/000276221

[13] VON DOBSCHUETZ E, LEIJON H, SCHALIN-JANTTI C, SCHIAVI F, BRAUCKHOFF $\mathrm{M}$ et al. A registry-based study of thyroid paraganglioma: histological and genetic characteristics. Endocr Relat Cancer 2015; 22: 191-204. https://doi. org/10.1530/ERC-14-0558

[14] RINALDO A, MYSSIOREK D, DEVANEY KO, FERLITO A. Which paragangliomas of the head and neck have a higher rate of malignancy? Oral Oncol 2004; 40: 458-460.

[15] MARTUCCI V, PACAK K. Pheochromocytoma and paraganglioma: diagnosis, genetics, management, and treatment. Curr Probl Cancer 2014; 38: 7-41. https://doi.org/10.1016/j. currproblcancer.2014.01.001

[16] ELSE T, GREENBERG S, FISHBEIN L. Hereditary Paraganglioma-Pheochromocytoma Syndromes. In: MP Adam, HH Ardinger, RA Pagon, SE Wallace, LJH Bean et al (Eds.). GeneReviews [Internet]. University of Washington, Seattle 1993-2019. Available at: http://www.ncbi.nlm.nih.gov/ books/NBK1548. Accessed November 19, 2018.

[17] PICCINI V, RAPIZZI E, BACCA A, DI TRAPANI, PULLI R et al. Head and neck paragangliomas: genetic spectrum and clinical variability in 79 consecutive patients. Endocr Relat Cancer 2012; 19: 149-155. https://doi.org/10.1530/erc-110369

[18] NEUMANN H, ERLIC Z, BOEDEKER C, RYBICKI L, ROBLEDO $\mathrm{M}$ et al. Clinical predictors for germline mutations in head and neck paraganglioma patients: cost reduction strategy in genetic diagnostic process as fall-out. Cancer Res 2009; 69, 3650-3656. https://doi.org/10.1158/0008-5472. can-08-4057

[19] LATIF F, TORY K, GNARRA JR, YAO M, DUH FM et al. Identification of the von Hippel-Lindau disease tumor suppressor gene. Science 1993; 260: 1317-1320. https://doi. org/10.1126/science. 8493574

[20] ENG C. The RET proto-oncogene in multiple endocrine neoplasia type 2 and Hirschprung's disease. N Engl J Med 1996; 335: 943-951. https://doi.org/10.1056/ NEJM199609263351307

[21] WHITE R, VISKOCHIL D, O'CONNELL P. Identification and characterization of the gene for neurofibromatosis type 1. Curr Opin Neurobiol 1991; 1: 462-467. https://doi. org/10.1016/0959-4388(91)90070-N

[22] NEUMANN HP, BAUSCH B, MCWHINNEY SR, BENDER $\mathrm{BU}, \mathrm{GIMM} \mathrm{O}$ et al. Germ line mutations in nonsyndromic pheochromocytoma. N Engl J Med 2002; 346: 1459-1466. https://doi.org/10.1056/NEJMoa020152 
[23] BAYSAL B, FERRELL R, WILLETT-BROZICK J, LAWRENCE E, MYSSIOREK D et al. Mutations in SDHD, a Mitochondrial Complex II Gene, in Hereditary Paraganglioma. Science. 2000; 287: 848-851. https://doi.org/10.1126/science.287.5454.848

[24] ASTUTI D, LATIF F, DALLOL A, DAHIA P, DOUGLAS F et al. Gene mutations in the succinate dehydrogenase subunit SDHB cause susceptibility to familial pheochromocytoma and to familial paraganglioma. Am J Hum Genet 2001; 69: 49-54. https://doi.org/10.1086/321282

[25] NIEMANN S, MULLER U. Mutations in SDHC cause autosomal dominant paraganglioma, type 3. Nat Genet 2000; 26: 268-270. https://doi.org/10.1038/81551

[26] BURNICHON N, BRIERE J, LIBE R, VESCOVO L, RIVIERE J et al. SDHA is a tumor suppressor gene causing paraganglioma. Human Mol Genet 2010; 19: 3011-3020. https:// doi.org/10.1093/hmg/ddq206

[27] QIN Y, YAO L, KING EE, BUDDAVARAPU K, LENCI RE et al. Germline mutations in TMEM127 confer susceptibility to pheochromocytoma. Nat Genet 2010; 42: 229-233. https:// doi.org/10.1038/ng.533

[28] COMINO-MENDEZ I, GRACIA-AZNAREZ FJ, SCHIAVI F, LANDA I, LEANDRO-GARCIA LJ et al. Exome sequencing identifies MAX mutations as a cause of hereditary pheochromocytoma. Nat Genet 2011; 43: 663-667. https://doi. org/10.1038/ng.861

[29] CASTRO-VEGA L, LETOUZE E, BURNICHON N, BUFFET A, DISDEROT PH et al. Multi-omics analysis defines core genomic alterations in pheochromocytomas and paragangliomas. Nat Commun 2015; 6: 6044. https://doi. org/10.1038/ncomms7044

[30] GIMENEZ-ROQUEPLO A, DAHIA P, ROBLEDO M. An update on the genetics of paraganglioma, pheochromocytoma, and associated hereditary syndromes. Horm Metab Res 2012; 44: 328-333. https://doi.org/10.1055/s-0031-1301302

[31] SCHLISIO S, KENCHAPPA RS, VREDEVELD LC, GEORGE RE, STEWART R et al. The kinesin KIF1Bbeta acts downstream from EglN3 to induce apoptosis and is a potential 1p36 tumor suppressor. Genes Dev 2008; 22: 884-893. https://doi.org/10.1101/gad.1648608

[32] LADROUE C, CARCENAC R, LEPORRIER M, GAD S, LE HELLO C et al. PHD2 mutation and congenital erythrocytosis with paraganglioma. N Engl J Med 2008; 359: 2685-2692. https://doi.org/10.1056/NEJMoa0806277

[33] GAAL J, BURNICHON N, KORPERSHOEK E, RONCELIN I, BERTHERAT J et al. Isocitrate dehydrogenase mutations are rare in pheochromocytomas and paragangliomas. J Clin Endocrinol Metab 2010; 95: 1274-1278. https://doi. org/10.1210/jc.2009-2170

[34] ZHUANG Z, YANG C, LORENZO F, MERINO M, FOJO $\mathrm{T}$ et al. Somatic HIF2A gain-of-function mutations in paraganglioma with polycythemia. N Engl J Med 2012; 367: 922930. https://doi.org/10.1056/nejmoa1205119

[35] OUDIJK L, DE KRIJGER RR, RAPA I, BEUSCHLEIN F, DE CUBAS AA et al. H-RAS mutations are restricted to sporadic pheochromocytomas lacking specific clinical or pathological features: data from a multi-institutional series. J Clin Endocrinol Metab 2014; 99: E1376-E1380. https://doi. org/10.1210/jc.2013-3879
[36] DE CUBAS AA, LEANDRO-GARCIA LJ, SCHIAVI F, MANCIKOVA V, COMINO-MENDEZ I et al. Integrative analysis of miRNA and mRNA expression profiles in pheochromocytoma and paraganglioma identifies genotype-specific markers and potentially regulated pathways. Endocr Relat Cancer 2013; 20: 477-493. https://doi.org/10.1530/erc-12-0183

[37] LETOUZE E, MARTINELLI C, LORIOT C, BURNICHON $\mathrm{N}$, ABERMIL $\mathrm{N}$ et al. SDH mutations establish a hypermethylator phenotype in paraganglioma. Cancer Cell 2013; 23: 739-752. https://doi.org/10.1016/j.ccr.2013.04.018

[38] DE CUBAS AA, KORPERSHOEK E, INGLADA-PEREZ L, LETOUZE E, CURRAS-FREIXES $M$ et al. DNA Methylation Profiling in Pheochromocytoma and Paraganglioma Reveals Diagnostic and Prognostic Markers. Clin Cancer Res 2015; 21: 3020-3030. https://doi.org/10.1158/1078-0432.ccr-142804

[39] BURNICHON N, BUFFET A, GIMENEZ-ROQUEPLO A. Pheochromocytoma and paraganglioma: molecular testing and personalized medicine. Curr Opin Oncol 2016; 28: 5-10. https://doi.org/10.1097/cco.0000000000000249

[40] CRONA J, DELGADO VERDUGO A, MAHARJAN R, STALBERG P, GRANBERG D et al. Somatic mutations in H-RAS in sporadic pheochromocytoma and paraganglioma identified by exome sequencing. J Clin Endocrinol Metab 2013; 98: E1266-E1271. https://doi.org/10.1210/jc.20124257

[41] EISENHOFER G, HUYNH T, PACAK K, BROUWERS F, WALTHER $M$ et al. Distinct gene expression profiles in norepinephrine- and epinephrine-producing hereditary and sporadic pheochromocytomas: activation of hypoxiadriven angiogenic pathways in von Hippel-Lindau syndrome. Endocr Relat Cancer 2004; 11: 897-911. https://doi. org/10.1677/erc. 1.00838

[42] DAHIA P, ROSS K, WRIGHT M, HAYASHIDA CY, SANTAGATA $S$ et al. A HIFlalpha regulatory loop links hypoxia and mitochondrial signals in pheochromocytomas. PLoS Genet 2005; 1: 72-80. https://doi.org/10.1371/journal. pgen.0010008

[43] LOPEZ-JIMENEZ E, GOMEZ-LOPEZ G, LEANDRO-GARCIA L, MUNOZ I, SCHIAVI F et al. Research resource: Transcriptional profiling reveals different pseudohypoxic signatures in SDHB and VHL-related pheochromocytomas. Mol Endocrinol 2010; 24: 2382-2391. https://doi.org/10.1210/ me.2010-0256

[44] BURNICHON N, VESCOVO L, AMAR L, LIBE R, DE REYNIES A et al. Integrative genomic analysis reveals somatic mutations in pheochromocytoma and paraganglioma. Hum Mol Genet 2011; 20: 3974-3985. https://doi. org/10.1093/hmg/ddr324

[45] BAYLEY J, KUNST H, CASCON A, SAMPIETRO ML, GAAL J et al. SDHAF2 mutations in familial and sporadic paraganglioma and phaeochromocytoma. Lancet Oncol 2010; 11: 366-372. https://doi.org/10.1016/S14702045(10)70007-3

[46] FAVIER J, BRIERE JJ, BURNICHON N, RIVIERE J, VESCOVO L et al. The Warburg effect Is genetically determined in inherited pheochromocytomas. PLoS One 2009; 4: e7094. https://doi.org/10.1371/journal.pone.0007094 
[47] PASINI B, STRATAKIS C. SDH mutations in tumorigenesis and inherited endocrine tumors: lesson from the phaeochromocytoma-paraganglioma syndromes. J Intern Med 2009; 266: 19-42. https://doi.org/10.1111/j.13652796.2009.02111.x

[48] BURNICHON N, ROHMER V, AMAR L, HERMAN P, LEBOULLEUX $S$ et al. The succinate dehydrogenase genetic testing in a large prospective series of patients with paragangliomas. J Clin Endocrinol Metab 2009; 94: 2817-2827. https:// doi.org/10.1210/jc.2008-2504

[49] SCHIAVI F, DEMATTE S, CECCHINI ME, TASCHIN E, BOBISSE $S$ et al. The endemic paraganglioma syndrome type 1: Origin, spread, and clinical expression. J Clin Endocrinol Metab 2012; 97: E637-641. https://doi.org/10.1210/jc.20112597

[50] BENN D, GIMENEZ-ROQUEPLO A, REILLY J, BERTHERAT J, BURGESS J et al. Clinical presentation and penetrance of pheochromocytoma/paraganglioma syndromes. J Clin Endocrinol Metab 2006; 91: 827-836. https://doi. org/10.1210/jc.2005-1862

[51] VAN DUINEN N, CORSSMIT E, DE JONG W, BROOKMAN D, KEMA I et al. Plasma levels of free metanephrines and 3-methoxytyramine indicate a higher number of biochemically active HNPGL than 24-h urinary excretion rates of catecholamines and metabolites. Eur J Endocrinol 2013; 169: 377-382. https://doi.org/10.1530/eje-13-0529

[52] VAN SCHOTHORST EM, JANSEN JC, GROOTERS E, PRINS DE, WIERSINGA JJ et al. Founder effect at PGL1 in hereditary head and neck paraganglioma families from the Netherlands. Am J Hum Genet 1998; 63: 468-473. https:// doi.org/10.1086/301951

[53] VAN DER MEY AG, MAASWINKEL-MOOY PD, CORNELISSE CJ, SCHMIDT PH, VAN DE KAMP JJ. Genomic imprinting in hereditary glomus tumours: evidence for new genetic theory. Lancet 1989; 2: 1291-1294. https://doi. org/10.1016/s0140-6736(89)91908-9

[54] PIGNY P, VINCENT A, CARDOT BAUTERS C, BERTRAND M, DE MONTPREVILLE VT et al. Paraganglioma after maternal transmission of a succinate dehydrogenase gene mutation. J Clin Endocrinol Metab 2008; 93: 16091615. https://doi.org/10.1210/jc.2007-1989

[55] HENSEN E, BAYLEY J. Recent advances in the genetics of SDH-related paraganglioma and pheochromocytoma. Fam Cancer 2011; 10: 355-363. https://doi.org/10.1007/s10689010-9402-1

[56] NEUMANN HP, PAWLU C, PECZKOWSKA M, BAUSCH B, MCWHINNEY SR et al. Distinct clinical features of paraganglioma syndromes associated with SDHB and SDHD gene mutations. JAMA 2004; 292: 943-951. https://doi. org/10.1001/jama.292.8.943

[57] HENSEN EF, JANSEN JC, SIEMERS MD, OOSTERWIJK JC, VRIENDS AH et al. The Dutch founder mutation SDHD.D92Y shows a reduced penetrance for the development of paragangliomas in a large multigenerational family. Eur J Hum Genet 2010; 18: 62-66. https://doi.org/10.1038/ ejhg.2009.112
[58] VAN HULSTEIJN LT, DEKKERS OM, HES FJ, SMIT JW, CORSSMIT EP. Risk of malignant paraganglioma in SDHBmutation and SDHD-mutation carriers: a systematic review and meta-analysis. J Med Genet 2012; 49: 768-776. https:// doi.org/10.1136/jmedgenet-2012-101192

[59] VICHA A, MUSIL Z, PACAK K. Genetics of pheochromocytoma and paraganglioma syndromes. Curr Opin Endocrinol Diabetes Obes 2013; 20: 186-191. https://doi.org/10.1097/ med.0b013e32835fcc 45

[60] NIEMANN S, MULLER U, ENGELHARDT D, LOHSE P. Autosomal dominant malignant and catecholamine-producing paraganglioma caused by a splice donor site mutation in SDHC. Hum Genet 2003; 113: 92-94. https://doi. org/10.1007/s00439-003-0938-0

[61] BAYSAL B, WILLETT-BROZICK J, FILHO P, LAWRENCE E, MYERS E et al. An Alu-Mediated partial SDHC deletion causes familial and sporadic paraganglioma. J Med Genet 2004; 41: 703-709. https://doi.org/10.1136/jmg.2004.019224

[62] SCHIAVI F, BOEDEKER C, BAUSCH B, PECZKOWSKA M, GOMEZ C. et al. Predictors and prevalence of paraganglioma syndrome associated with mutations of the SDHC gene. JAMA 2005; 294: 2057-2063. https://doi.org/10.1001/ jama.294.16.2057

[63] NEUMANN HP, ENG C. The approach to the patient with paraganglioma. J Clin Endocrinol Meta 2009; 94: 2677-2683. https://doi.org/10.1210/jc.2009-0496

[64] PROYE C, VIX M, GOROPOULOS A, KERLO P, LECOMTE-HOUCKE M. High incidence of malignant pheochromocytoma in a surgical unit: 26 cases out of 100 patients operated from 1971 to 1991. J Endocrinol Invest 1992; 15: 651-663. https://doi.org/10.1007/BF03345810

[65] RICKETTS C, FORMAN J, RATTENBERRY E, BRADSHAW N, LALLOO F et al. Tutor risks and genotype-phenotype-proteotype analysis in 358 patients with germline mutations in SDHB and SDHD. Hum Mutat 2010; 31: 41-51. https://doi.org/10.1002/humu.21136

[66] KLEIN RD, JIN L, RUMILLA K, YOUNG WF, LLOYD RV. Germline SDHB mutations are common in patients with apparently sporadic sympathetic paragangliomas. Diagn Mol Pathol. 2008; 17: 94-100. https://doi.org/10.1097/ PDM.0b013e318150d67c

[67] AMAR L, BAUDIN E, BURNICHON N, PEYRARD S, SILVERA $S$ et al. Succinate dehydrogenase B gene mutations predict survival in subjects with malignant pheochromocytomas or paragangliomas. J Clin Endocrinol Metab 2007; 92: 3822-3828. https://doi.org/10.1210/jc.2007-0709

[68] GIMENEZ-ROQUEPLO A, FAVIER J, RUSTIN P, RIEUBLAND C, CRESPIN M et al. Mutations in the SDHB gene are associated with extra-adrenal and/or malignant phaeochromocytomas. Cancer Res 2003; 63: 5615-5621.

[69] HAO H, KHALIMONCHUK O, SCHRADERS M, DEPHOURE N, BAYLEY J. et al. SDH5, a gene required for flavination of succinate dehydrogenase, is mutated in paraganglioma. Science 2009; 325: 1139-1142. https://doi. org/10.1126/science.1175689 
[70] VAN BAARS F, VAN DEN BROEK P, CREMERS C, VELDMAN J. Familial non-chromaffinic paragangliomas (glomus tumors): clinical aspects. Laryngoscope 1981; 91: 988-996. https://doi.org/10.1288/00005537-198106000-00019

[71] KUNST HP, RUTTEN M, DE MONNINK JP, HOEFSLOOT LH, TIMMERS HJ et al. SDHAF2 (PGL2-SDH5) and hereditary head and neck paraganglioma. Clin Cancer Res 2011; 17: 247-254. https://doi.org/10.1158/1078-0432.ccr-10-0420

[72] OFFERGELD C, BRASE C, YAREMCHUK S, MADER $\mathrm{I}$, RISCHKE $\mathrm{H}$ et al. Head and neck paragangliomas: clinical and molecular genetic classification. Clinics (Sao Paulo) 2012; 67 Suppl 1: 19-28. https://doi.org/10.6061/ clinics/2012(Sup01)05

[73] KARASEK D, SHAH U, FRYSAK Z, STRATAKIS C, PACAK K. An update on the genetics of pheochromocytoma. J Hum Hypertens 2013; 27: 141-147. https://doi.org/10.1038/ jhh.2012.20

[74] BOEDEKER C, ERLIC Z, RICHARD, S, KONTNY U, GIMENEZ-ROQUEPLO A. et al. Head and neck paragangliomas in von Hippel-Lindau disease and multiple endocrine neoplasia type 2. J Clin Endocrinol Metab 2009; 94: 1938 1944. https://doi.org/10.1210/jc.2009-0354

[75] PACAK K, JOCHMANOVA I, PRODANOV T, YANG C, MERINO MJ et al. New syndrome of paraganglioma and somatostatinoma associated with polycythemia. J Clin Oncol 2013; 31: 1690-1698. https://doi.org/10.1200/ JCO.2012.47.1912

[76] LORENZO FR, YANG C, NG TANG FUI M, VANKAYALAPATI H, ZHUANG Z et al. A novel EPAS1/HIF2A germline mutation in a congenital polycythemia with paraganglioma. J Mol Med (Berl) 2013; 91: 507-512. https://doi.org/10.1007/ s00109-012-0967-z

[77] WALLACE MR, MARCHUK DA, ANDERSEN LB, LETCHER R, ODEH HM et al. Type 1 neurofibromatosis gene: identification of a large transcript disrupted in three NF1 patients. Science 1990; 249: 181-186. https://doi.org/10.1126/ science. 2134734

[78] BURNICHON N, BUFFET A, PARFAIT B, LETOUZE E, LAURENDEAU I et al. Somatic NF1 inactivation is a frequent event in sporadic pheochromocytoma. Hum Mol Genet 2012; 21: 5397-5405. https://doi.org/10.1093/hmg/ dds374

[79] DEANGELIS LM, KELLEHER MB, POST KD, FETELL MR. Multiple paragangliomas in neurofibromatosis: a new neuroendocrine neoplasia. Neurology 1987; 37: 129-133. https:// doi.org/10.1212/wnl.37.1.129

[80] BAUSCH B, BOROZDIN W, NEUMANN HP, EUROPEAN-AMERICAN PHEOCHROMOCYTOMA STUDY GROUP. Clinical and genetic characteristics of patients with neurofibromatosis type 1 and pheochromocytoma. N Engl J Med 2006; 354: 2729-2731. https://doi.org/10.1056/ NEJMc066006

[81] ABERMIL N, GUILLAUD-BATAILLE M, BURNICHON $\mathrm{N}$, VENISSE A, MANIVET $\mathrm{P}$ et al. TMEM127 screening in a large cohort of patients with pheochromocytoma and/or paraganglioma. J Clin Endocrinol Metab 2012; 97: E805E809. https://doi.org/10.1210/jc.2011-3360
[82] BURNICHON N, CASCON A, SCHIAVI F, MORALES NP, COMINO-MENDEZ I et al. MAX mutations cause hereditary and sporadic pheochromocytoma and paraganglioma. Clin Cancer Res 2012; 18: 2828-2837. https://doi. org/10.1158/1078-0432.CCR-12-0160

[83] IVAN HT, HABERBERGER T, GERVASI DC, MICHELSON KS, GUNZLER V et al. Biochemical purification and pharmacological inhibition of a mammalian prolyl hydroxylase acting on hypoxia-inducible factor. Proc Natl Acad Sci U S A 2002; 99: 13459-13464. https://doi.org/10.1073/ pnas. 192342099

[84] ADARI H, LOWY DR, WILLUMSEN BM, DER CJ, MCCORNICK F. Guanosine triphosphatase activatingprotein (GAP) interacts with the p21 ras effector binding domain. Science 1988; 240: 518-521. https://doi.org/10.1126/science. 2833817

[85] KING KS, PACAK K. Familial pheochromocytomas and paragangliomas. Mol Cell Endocrinol 2014; 386: 92-100. https://doi.org/10.1016/j.mce.2013.07.032

[86] SRIDHARA SK, YENER M, HANNA E, RICH T, JIMENEZ $\mathrm{C}$ et al. Genetic testing in head and neck paraganglioma: who, what, and why? J Neurol Surg B Skull Base 2013; 74: 236-240. https://doi.org/10.1055/s-0033-1342924

[87] FAKHRY N, NICCOLI-SIRE P, BARLIER-SETI A, GIORGI R, GIOVANNI A at al. Cervical paragangliomas: is $\mathrm{SDH}$ genetic analysis systematically required? Eur Arch Otorhinolaryngol 2008; 265: 557-563. https://doi.org/10.1007/ s00405-007-0517-4

[88] ZHU WD, WANG ZY, CHAI YC, WANG XW, CHEN DY et al. Germline mutations and genotype-phenotype associations in head and neck paraganglioma patients with negative family history in China. Eur J Med Genet 2015; 58: 433-438. https://doi.org/10.1016/j.ejmg.2015.05.008

[89] HEESTERMAN BL, BAYLEY JP, TOPS CM, HES FJ, VAN BRUSSEL BT et al. High prevalence of occult paragangliomas in asymptomatic carriers of SDHD and SDHB gene mutations. Eur J Hum Genet 2013; 21: 469-470. https://doi. org/10.1038/ejhg.2012.203

[90] WELANDER J, LARSSO C, BACKDAHL M, HARENI N, SIVLER $T$ et al. Integrative genomics reveals frequent somatic NF1 mutations in sporadic pheochromocytomas. Hum Mol Genet 2012; 21: 5406-5416. https://doi.org/10.1093/ hmg/dds402

[91] CHEN H, ZHU W, LI X, XUE L, WANG Z et al. Genetic and epigenetic patterns in patients with the head- and-neck paragangliomas associate with differential clinical characteristics. J Cancer Res Clin Oncol 2017; 143: 953-960. https:// doi.org/10.1007/s00432-017-2355-0

[92] ZHIKRIVETSKAYA SO, SNEZHKINA AV, ZARETSKY AR, ALEKSEEV BY, POKROVSKY AV et al. Molecular markers of paragangliomas/pheochromocytomas. Oncotarget 2017; 8: 25756-25782. https://doi.org/10.18632/oncotarget.15201 